\title{
A Multimedia Based Virtual Learning System: A Panacea for Nigerian Tertiary Institutions
}

\author{
Emmanuel Nwabueze Ekwonwune1, Chidiebere Chukwuma Oparah² \\ ${ }^{1}$ Department of Computer Science, Imo State University, Owerri, Nigeria \\ ${ }^{2}$ Department of Computer Science, Federal Polytechnic, Nekede, Owerri, Nigeira \\ Email:ekwonwuneemmanuel@yahoo.com,canonchychuks@yahoo.com
}

How to cite this paper: Ekwonwune, E.N. and Oparah, C.C. (2020) A Multimedia Based Virtual Learning System: A Panacea for Nigerian Tertiary Institutions. Circuits and Systems, 11, 1-9.

https://doi.org/10.4236/cs.2020.111001

Received: August 14, 2019

Accepted: January 28, 2020

Published: January 31, 2020

Copyright $\odot 2020$ by author(s) and Scientific Research Publishing Inc. This work is licensed under the Creative Commons Attribution International License (CC BY 4.0).

http://creativecommons.org/licenses/by/4.0/

(c) (i) Open Access

\begin{abstract}
Multimedia based virtual learning system (MMVLS) is a web-based platform for teaching and learning with a virtual teacher within a virtual classroom. This research was motivated by the problems confronting the traditional institutions of higher learning in Nigeria which include inadequate funding, lack of infrastructures, inadequate teaching and learning facilities, limited slots for admission known as carrying capacity, a limited number of lecturers/instructors in the tertiary institutions in Nigeria. The objective of this research is to develop a multimedia based virtual learning system for Nigerian tertiary institutions to be used in academic processes for teaching and learning. The methodology used is Object Oriented Design Methodology (OODM) with the following web development tools PHP, JavaScript, Bootstrap 3, HTML5, CSS4, Apache, and MYSQL as database. The expected result is a multimedia based virtual learning system for tertiary institutions in Nigeria which is cost effective, innovative, vibrant, individualized, learner-centric, available anytime, any place even with mobile devices. It was concluded that multimedia based virtual learning system is a veritable tool for Nigerian tertiary institutions, which when fully implemented by Nigerian tertiary institutions would help to increase the number of candidates that are given admission into our tertiary institutions and drastically reduce school dropouts as a result of candidates not gaining admission due to insufficient tertiary institutions/carrying capacity.
\end{abstract}

\section{Keywords}

Multimedia, Virtual Learning, Examination, Assessment, Tertiary Institution

\section{Introduction}

In Nigeria, there is an insufficient number of tertiary institution and as such 
there is a need for the extension of the physical institutions of higher learning into virtual institutions so as to accommodate the number of persons applying for admission into our institutions of higher learning. This will help more candidates to be given admission into institutions of higher learning by Joint Admission Matriculation Board (JAMB).

Daily Trust states that there are insufficient tertiary institutions with low carrying capacities and as such Nigerian tertiary institutions can only admit $26 \%$ of applicants from Unified Tertiary Matriculation Examination conducted by JAMB due to limited vacancies [1]. It was confirmed that over 10 million students sought admission through Unified Tertiary Matriculation Examination (UTME) into higher institutions of learning in six years (2010-2015) but only 2,674,485 candidates were admitted [2]. And the remaining $74 \%$ were returned to write the Unified Tertiary Matriculation Examination (UTME) with other secondary school leavers that will be joining the subsequent years. The growing trend of candidates not admitted is alarming. In 2016, a total of 1,009,175 registered for UTME, 1,736,571 and 1,662,762 registered in 2017 and 2018 respectively [2].

Nigeria with 158 universities and 115 polytechnics, colleges of education and monotechnics, with carrying capacity that is slightly above 600,000 with average of 1.6 million UTME candidates registering every year, it becomes impossible for the traditional tertiary institutions to admit them even when most of them are qualified to be admitted [1] [2]. No wonder Adesulu advocates that Nigeria needs one million varsity spaces in his write-up entitled "Nigeria: Jamb admission shortfall-Nigeria needs one million varsity spaces" in order to accommodate Jamb admission short fall. According to Adesulu, the already existing institutions are not sufficient to admit all UTME qualified candidates with the impending problems of the already existing tertiary institutions in Nigeria which include lack of funding, lack of infrastructures, lack of maintenance of existing infrastructures/infrastructural decay, a limited number of lecturers/instructors, among others. These problems have been causing incessant strike actions in the country.

Besides, Nigeria with over 180 million populations has only about 290 tertiary institutions across the 36 states of the federation including Abuja the Federal Territory [2].

The fact remains that the physical tertiary institutions with their impending problems cannot handle the increasing number of candidates applying through Jamb admissions. In order to handle the increasing number of candidates that qualify to be given admission, yet are not admitted because of insufficient tertiary institutions and other impending problems, it becomes necessary that an alternative to the physical tertiary institutions should be made. This alternative is a multimedia based virtual learning system (MMVLS) for Nigerian tertiary institutions which integrate all the tertiary institutions into one platform for teaching/learning and handling other academic processes in institutions of higher learning in Nigeria. 
Multimedia based virtual learning system is a web-based platform for teaching and learning with a virtual teacher within a virtual classroom. The multimedia based virtual learning system is a virtual learning environment (VLE) with a web-based platform for the digital aspects of courses of study, usually within educational institutions [3]. It presents resources, activities and interactions within a course structure and provide learning for different stages of assessment. This by implication is to have virtual (Online) institution for higher learning in Nigeria to complement the already existing traditional institutions of higher learning; where all educational infrastructures/education are provided virtually. The multimedia based virtual learning system when implemented will be able to accommodate as many students as possible as there is no limit to the number of students it can take or admit. Besides, the Multimedia based virtual learning system (MMVLS) provides an opportunity for individualized instruction according to the approved curriculum. Multimedia based virtual learning system (MMVLS) is interactive, vibrant, innovative, user-friendly with self-testing and automated assessment, and grants access to many users from different locations anytime, any day. This is simply an integrated online version of Nigerian tertiary educational institutions hence the research work entitled "A multimedia based virtual learning system for Nigerian tertiary institutions".

\section{Literature Review}

Multimedia based virtual learning system (MMVLS) is a web-based platform for teaching and learning with a virtual teacher within a virtual classroom. The multimedia based virtual learning system is a virtual learning environment (VLE) which is web-based platform for the digital aspects of courses of study, usually with educational institutions [3]. MMVLS presents resources, activities and interactions within a course structure and provides learning for different stages of assessment.

MMVLS as a virtual learning environment reports on participation and have some level of integration with either institutional system.

The virtual learning platform includes the following components according to

[3] [4]:

$>$ Content management-creation, storage, access to and use of learning resources.

Curriculum mapping and planning-lesson planning, assessment and personalization of the learning experience.

$>$ Learner engagement and administration-managed access to learner information and resources and tracking of progress and achievement.

> Communication and collaboration-emails, notices, chats, wikis, blog.

Real time communication-live video conferencing or audio conferencing. A VLE may include some or all of the following elements:

$>$ The course syllabus.

Administrative information about the course: prerequisites, credits, registra- 
tion, payments, physical sessions and contact information.

The notice board for current information about the ongoing course.

The basic content of some or all the course, the complete course for distance learning applications, or some part of it, when used as a portion of a conventional course. This includes materials such as copies of lecture in the form of text, audio, or video presentations, and the supporting visual presentation.

Additional resources, either integrated or as links to outside resources.

Self-assessment quizzes or analogue devices normally scored automatically.

Formal assessment functions such as examinations, assay submission or presentation of projects [3] [4]. The formal assessment function of the Virtual Learning system now includes components to support peer assessment.

> Support for communications including e-mail, threaded discussions, chat rooms, twitter and other media sometimes with the instructor or an assistant media as moderator. Additional elements include wikis, blogs, RSS and 3D virtual learning spaces.

> Links to outside sources-pathways to all other online learning spaces are linked via the virtual learning environment.

Management of access rights for instructors, their assistants, course support staff and students.

Documentation and statistics as required for institutional administration and quality control.

$>$ Authority tools creating the necessary documents by the instructor and usually submissions by the students.

$>$ Provision for the necessary hyperlinks to create a unified presentation to the students.

Interactive online whiteboard for live virtual classes.

A virtual learning environment is normally not designed for a specific course or subject, but it is capable of supporting multiple courses over the full range of the academic programme, giving a consistent interface within the institution and to some degree with other institutions using the system. The virtual learning environment supports the world wide exchange of information between a user and the learning institute he or she is currently enrolled in through digital mediums like e-mail, chat rooms, web 2.0 site or a forum [3] [4].

Some basic characteristics of virtual learning according to [5] include: remote access to an unlimited array of educational services (topics and tutors) offered worldwide; individualized learning process that takes into consideration the personal level of competence, individual needs, and different learning styles; safe and secure learning environment; Flexible learning in terms of time, location, and pace; and cost-effectiveness, time-effective, easily scalable.

Adeyeye, Afolabi and Ayodeveloped a virtual learning for Covenant University, Ota, a private institution based on third party software free open source software (FOSS) called phpBB and windows 2003 server Active Directory with a discussion forum and directory services for files/folders upload and download of 
lecturer notes, mail services and test/tutorial [6]. This system only aid students to learn more on their own not for a full course of study and besides there is no provision for the official assessment (examination) of the students by the lecturer.

Kimovski, Trajkovic and Davcevcarried out a study that integrates virtual classroom and virtual laboratory services of which virtual classroom was only a part of the virtual university but there is no integrated official examination system [7].

In a study carried out by Anekweon "Impacts of Virtual Classroom Learning on students' of Nigerian Federal and State universities", she advocates strongly that tertiary institutions in Nigeria should integrate virtual learning effectively into their systems because the world is becoming more technologically inclined. The study was carried out using stratified random sampling and the data collected were analysed using means for research questions and independent sample $t$-test to test the hypotheses at 0.05 level of significance. The results showed among others that virtual classrooms have positive impacts on the students of both states and federal universities and she recommended that the Nigerian Federal and state universities should as a matter of urgency provide adequate and dependable virtual learning environment, application software and the necessary technological tools including an effective time schedule for students learning, adding that the private universities should also do the same [8].

Based on Anikwe's findings and recommendations, the present researchers proposed to develop a multimedia based virtual learning system for on line education with the approved academic curriculum for courses of study in tertiary institutions in Nigeria with an authenticated examination and assessment system to produce a virtual learning system for Nigerian tertiary institutions.

\section{Statement of Problem}

The institutions of higher learning in Nigeria are being saddled with the problems such as

- Inadequate funding.

- Lack of infrastructures.

- Inadequate teaching and learning facilities.

- Problem of access road to the institutions.

- Insecurity.

- Limited vacancies/slots for admission known as carrying capacity.

- Very high student-lecturer ratio due to lack of lecturers/instructors.

- Besides, there is limited number of tertiary institutions in Nigeria compare with the growing population of the country.

Because of the above problems, the institutions of higher learning in Nigeria are not able to admit all the qualified candidates who apply for Unified Tertiary Matriculation Board Examination. This problem further escalates the problem of out-of-school/school dropouts in Nigeria as about $74 \%$ of candidates that applied for higher education through the Unified Tertiary Matriculation Board 
Examination (UTME) cannot be absorbed by the already available tertiary institutions in Nigeria [2].

It was against these existing problems that this research seeks to proffer solution through the development of a multimedia based virtual learning system for Nigerian tertiary institutions.

A multimedia based virtual learning system for Nigerian tertiary institutions is an integrated online tertiary education in Nigeria where education can be made available to all who seek to have it, with needed infrastructures and facilities made available anytime, anyplace thereby, avoiding the risk of traveling and accessed to bad roads, handling the problem of limited lecturers/instructors as the educational materials (lectures) can serve an unlimited number of students in the area. Besides, students can learn at their pace without fear or intimidation with the guidance of virtual lecturer. The online students can interact with other colleagues within and outside the school environment like the traditional institutions. They can seek clarifications on issues of concern and have a feel of what goes on in the traditional institutions virtually.

\section{Aim and Objectives of the Study}

This study is aimed at the development of a multimedia based virtual learning system for Nigerian tertiary institutions to be used in academic processes for teaching and learning with the following objectives:

1) To develop a virtual learning platform for Nigerian tertiary institutions.

2) To register learners (students) and lecturers to be able to identify authorized users of the platform.

3) To register and administer lectures to registered students based on the approved curriculum.

4) To provide an authentication system for examination administration.

5) To provide forum or platform for questions by the students on issues that need clarification by their lecturers/instructors or fellow students.

6) To access students' performance after learning.

\section{Significance of the Study}

This research work develops a multimedia based virtual learning system for tertiary institutions in Nigerian. Multimedia based virtual learning system is a web based learning system which is used for academic processes for teaching and learning which is interactive, vibrant, user-friendly, and innovative for educational empowerment, which can be assessed anywhere, anytime.

* It will serve as a platform to increase the number of intake/enrolment into our institutions of higher learning in Nigeria as it is the extension of the traditional tertiary institutions into virtual institution.

* It will be available for the students at all times and in all places for learning and also enables them to learn from their counterparts and others.

* It will be an avenue to reducing the increasing number of school dropouts 
caused by the struggles to gain admission into institutions of higher learning who became frustrated as they cannot be admitted because of limited vacancies/admission slots in tertiary institutions.

* It will be an opportunity to expand the carrying capacities of the institutions of higher learning in Nigeria as the web can accommodate an unlimited number of persons to study.

* It will augment the efforts of the lecturers/instructors in reaching the unreached in the country thereby reducing the number of out of school and increase the literacy level of the country.

* It will also provide study materials for students for learning and also cause them to be determined/serious with their studies as there is specified duration for one to graduate as applicable to traditional institutions. This is to inculcate the spirit of seriousness in the students to know that the programme is being monitored.

* It will also eliminate examination malpractice as the event is monitored and examination administered to authentic persons.

* It will serve as an aid to appropriate stakeholders on education such as JAMB, Ministry of Education and different bodies for tertiary institutions in Nigeria to handle admission process and follow the trend of study in Nigeria tertiary institutions.

* It will be cost effective as there may not be need to duplicate efforts in developing materials/resources to be used as any adopted materials/resources can be used by all institutions.

* The idea of who teaches, examines will be eliminated as there will be centrally adopted examination to be written for every course of study. This will further improve the standard of education as no single lecturer/instructor will be responsible for setting examination questions.

* This work is not a terminus, therefore; it also gives room for improvement especially for researchers who may be interested in this area of research.

* It will also serve as a reference material for scholars and students who are interested in this area.

\section{Methodology}

\subsection{Source of Data}

The primary source of data was through the use of oral interview and observation. Other sources of data used in this study are books, journals, manuals and internet sources.

\subsection{Method of Data Analysis}

The method of analysis and design to be used in this work is Object Oriented Design Methodology (OODM). Object oriented analysis and design is a technical approach for analyzing and designing an application by applying object-oriented programming as well as using visual modelling throughout the de- 
velopment life cycle to faster better stakeholder communication and product quality. Object oriented analysis and design uses an iterative approach with emphasis on modularity and re-usability. Object oriented analysis and design combines both data and methods into cohesive unit and classes.

\subsection{Tools/Resources for Analysis and Assessment}

The following tools are to be used in the development of the system: PHP (Pre-Hypertext Processor), JavaScript, Bootstrap 3, HTML5 and CSS4, Apache (middleware) and MYSQL database for backend development.

\section{Conclusions}

This work was motivated by the problems confronting the traditional institutions of higher learning in Nigeria which include inadequate funding, lack of infrastructures, inadequate teaching and learning facilities, limited slots for admission known as carrying capacity, a limited number of lecturers/instructors in the tertiary institutions in Nigeria.

It is not a hidden fact that one of the challenges of Nigeria is education. Education has been an issue of concern to Nigeria. One in every five of the world's out-of-school children is in Nigeria according to National Bureau of Statistics [9].

The increasing use of technology in education especially with respect to electronic learning has given rise to having an alternative to leverage the problems usually encountered in the traditional face-to-face learning. These advances in e-learning have given birth to virtual learning system which has proven potentials of alleviating the problems in our tertiary institutions in Nigeria.

Multimedia Virtual learning system if effectively implemented across the nation's tertiary institutions will drive down the number of out-of-school children/school dropout across the country; especially those that are as a result of tertiary institutions not being able to admit them because of carrying capacity and infrastructures.

It is important to note that multimedia virtual learning system if implemented will make education to be cost effective, reachable, user dynamic, personalized, vibrant, viable option to expanding traditional schooling, build inter-disciplinary relationships among students while increasing base knowledge sharing, make the learning process user specific, intriguing and fun.

There is no doubt that multimedia based virtual learning is a veritable tool for Nigerian tertiary institutions. This will help to increase the number of candidates that are given admission into our tertiary institutions and drastically reduce school dropouts as a result of candidates not gaining admission due to insufficient tertiary institutions/carrying capacity.

\section{Recommendation}

Multimedia based Virtual learning is a veritable tool for Nigerian to eradicate 
out-of-school/school dropout especially among the secondary school leavers which is caused as a result of frustrations the people face in seeking for admission into institutions of higher learning in Nigeria. We therefore recommend that the government, the Ministry of education, different bodies for tertiary institutions in Nigeria should fully implement the multimedia based virtually learning system in Nigeria as it has promised to make education at tertiary level to be available anytime, anywhere to all who qualifies for Unified Tertiary Matriculation Board Examination. It is cost effective, monitored, interactive, individualized with vibrancy.

\section{Acknowledgements}

We want to acknowledge all the people who made contributions to this work especially the individuals who were consulted in the course of this work. We acknowledge and appreciate all the authors whose works were cited in this paper, in case of any omission, we sincerely apologize.

\section{Conflicts of Interest}

The authors declare no conflicts of interest regarding the publication of this paper.

\section{References}

[1] Abdallah N.M. (2017) Nigeria: 74 Percent of Applicants Don't Get University Admission. Daily Trust, 28 August 2017.

[2] Adesulu, D. (2018) Nigeria: Jamb Admission Short Fall-Nigeria Needs 1 M Varsity spaces. Vanguard Newspaper. https://allafrica.com/stories/20180503055.html

[3] Wikipedia (2019) The Free Encyclopedia "Virtual Learning System". https://en.wikipedia.org/wiki/virtual_learning_environment

[4] Holyoke, M. (2019) Virtual Learning Environment (VLE) or Managed Learning Environment (MLE). https://whatis.techtarget.com/definition/virtual_learning_environment

[5] Racheva, V. (2017) What Is Virtual Learning? https://www.vedamo.com/knowledge/tag/virtual-learning/

[6] Adeyeye, O.M., Afolabi, I.T. and Ayo, C.K. (2014) Virtual Learning in Nigeria Universities: A Panacea for Enhanced Academic Standards. International Journal for Innovation Education and Research, 2, 20114. https://www.ijier.net/ijier

[7] Kimovski, G. Trajkovic, V. and Davcev, D. (2001) Virtual Learning System. https://www.researchgate.net/publication/242405171

[8] Anekwe, J.U. (2017) Impacts of Virtual Classroom Learning on Students' of Nigerian Federal and State Universities. European Journal of Research and Reflection in Educational Sciences, 5, No. 3, 43.

[9] National Bureau of Statistics (2010) Report of the National Bureau of Statistics. The National Literacy Survey June, 2010. https://www.nigeriastat.gov.ng/pages/download/43 